\title{
Ammonoids from the Dalle des Iridet of the Mouydir and Ahnet (Central Sahara) and the Formation d'Hassi Sguilma of the Saoura Valley (Late Tournaisian-Early Viséan; Algeria)
}

\author{
Dieter Korn $^{*}, 1$, Volker Ebbighausen ${ }^{2}$ and Jürgen Bockwinkel ${ }^{3}$ \\ ${ }^{1}$ Museum für Naturkunde Berlin, Invalidenstraße 43, 10115 Berlin, Germany. E-mail: dieter.korn@mfn-berlin.de \\ ${ }^{2}$ Engstenberger Höhe 12, 51519 Odenthal, Germany. E-mail: Volker@vxr.de \\ ${ }^{3}$ Dechant-Feinstraße 22, 51375 Leverkusen, Germany. E-mail: jbockwinkel@t-online.de
}

Received 11 May 2009

Accepted 8 June 2009

Published 19 February 2010

\section{Key Words}

\section{Ammonoidea}

Mississippian

Carboniferous

North Africa

taxonomy

\begin{abstract}
Four ammonoid species are described from the Early Carboniferous (Mississippian) Iridet Formation of the Ahnet and Mouydir (Central Sahara, Algeria); three of which are new: Eurites temertassetensis n. sp., Trimorphoceras teguentourense n. sp., and Trimorphoceras azzelmattiense n. sp. The species can be attributed to the North African Ammonellipsites-Merocanites Assemblage (Fascipericyclus-Ammonellipsites Genus Zone; Late Tournaisian to Early Viséan). Additionally, the two new species Ammonellipsites sguilmensis $\mathrm{n}$. sp. and Muensteroceras beniabbesense $\mathrm{n}$. $\mathrm{sp}$. are described from the time equivalent Hassi Sguilma Formation of the Saoura Valley (north-western Algeria).
\end{abstract}

\section{Introduction}

The Iridet Formation (= Dalle des Iridet) is the first prominent carbonate horizon in the Early Carboniferous succession of Central Algeria (Conrad 1984; Wendt et al. 2009). It forms a highly visible calcareous marker horizon across wide distances in the regions of the Ahnet and Mouydir (Fig. 1) and varies in thickness from a few metres up to $170 \mathrm{~m}$. The carbonate horizon is not a single unit, but a sequence of several calcareous layers separated by shales. Ammonoids occur mainly at the base of the formation.

The Iridet Formation is largely a time equivalent of the Hassi Sguilma Formation near Béni Abbès in the Béchar Basin (Menchikoff 1930; Pareyn 1961) and the Dalle à Merocanites of Timimoun (Conrad 1984), but the precise relationships are not clear. Composition of the ammonoid faunas from the three regions differ to some degree, but resemble each other in the presence of typically latest Tournaisian and earliest Viséan taxa, i.e. the North African Ammonellipsites-Merocanites Assemblage (Korn et al. 2007; Fig. 2).

The present study can only provide preliminary results of the analysis of the ammonoids from the Iridet Formation and the Hassi Sguilma Formation. Much more field work is necessary to uncover the rich assemblages of the two formations. However, the available material will be described here for the first time to compliment the monographs of the early Late Tournaisian (Korn et al. 2010a, 2010b) as well as the Early and Middle Viséan (Bockwinkel et al. 2010) assemblages from Algeria.

\section{Material}

Ammonoids from several exposures of the Iridet Formation (Dalle des Iridet in Conrad 1984) in the Mouydir and Ahnet regions have been studied (for a detailed description of the localities, see Wendt et al. 2009):

\footnotetext{
* Corresponding author
} 

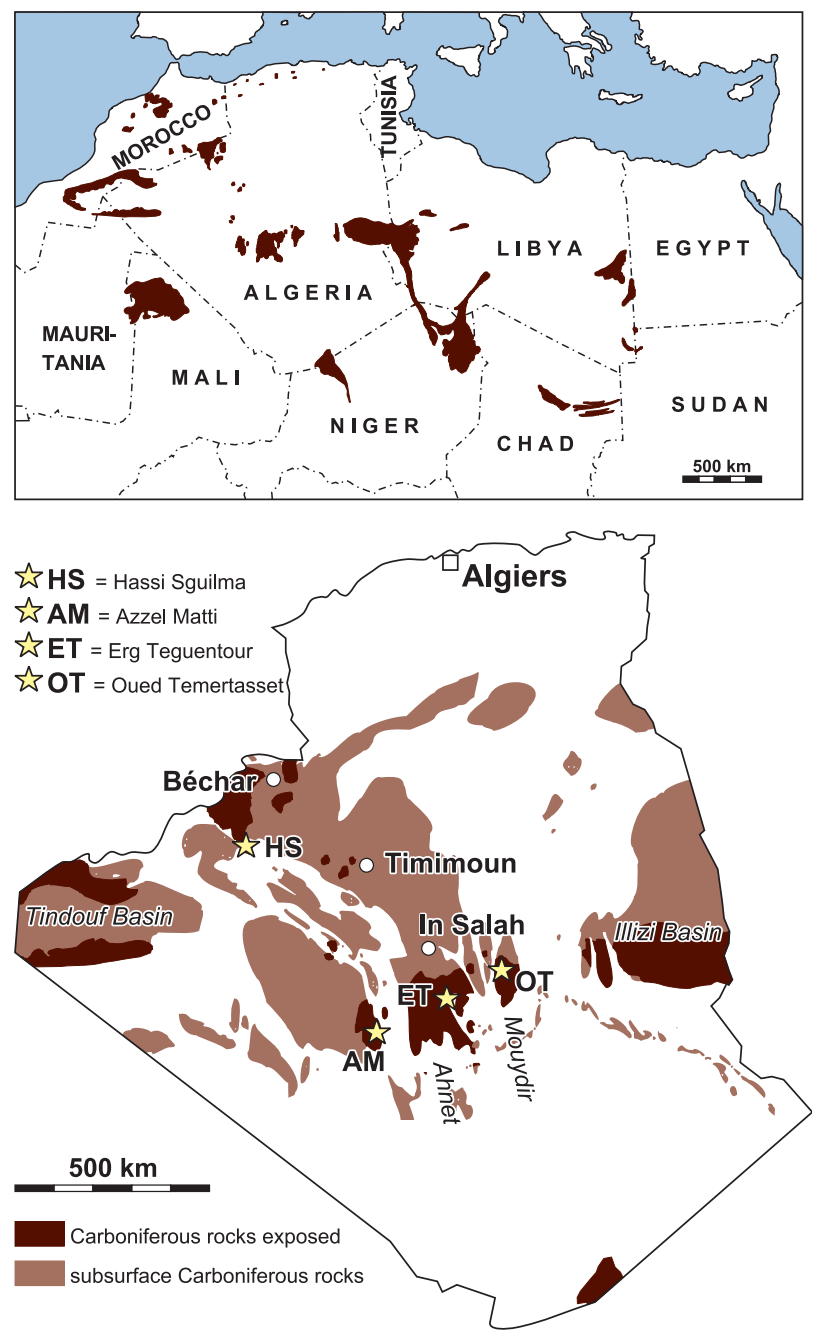

Figure 1. The outcrop of Palaeozoic rocks in northern Africa and the geographic position (marked by an asterisk) of the localities of the Iridet Formation and the Hassi Sguilma Formation.

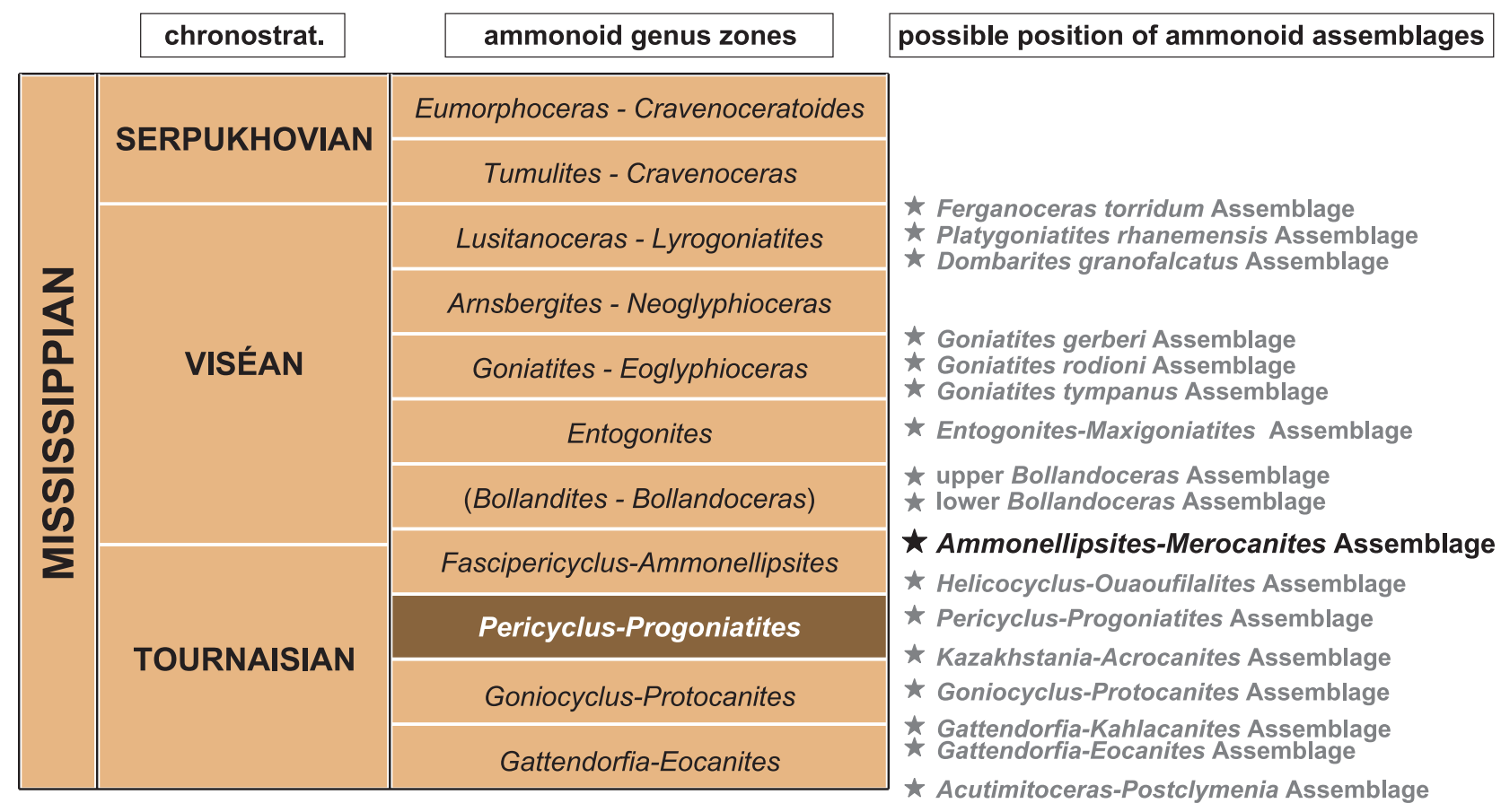

Figure 2. Stratigraphic scheme of the Early Carboniferous (Mississippian) chronostratigraphy and ammonoid zonation with correlation to the North African ammonoid assemblages (after Korn et al. 2004, 2007). The position of the fauna from the Iridet Formation and the Hassi Sguilma Formation is highlighted. 
Oued Temertasset (Mouydir), locality MOU-U; $26.6778^{\circ} \mathrm{N}, 3.8795^{\circ} \mathrm{E}$ (specimens collected by the authors and Dieter Weyer, 2002):

Eurites temertassetensis n. sp.

5 specimens (MB.C.18617.1-5)

Eurites sp.

1 specimen (MB.C.18618)

Trimorphoceras sp.

1 specimen (MB.C.18619)

Oued Temertasset (Mouydir); same locality (Wendt and Kaufmann Coll.):

Eurites temertassetensis n. sp.

1 specimen (MB.C.18620)

West-southwest of Gara Azzel Matti (Ahnet); $25.4732^{\circ} \mathrm{N}, \mathbf{0 . 7 0 6 7}^{\circ} \mathrm{E}$ (Wendt and Kaufmann Coll.):

Trimorphoceras azzelmattiense $\mathrm{n} . \mathrm{sp}$.

1 specimen (MB.C.18621)

Trimorphoceras sp.

3 specimens (MB.C.18622.1-3)

Erg Teguentour (Ahnet); 26.1433 ${ }^{\circ}$ N, 2.8418 ${ }^{\circ}$ E (Wendt \& Kaufmann Coll.):

Hammatocyclus sp.

Eurites commutatus Ebbighausen et al., 2010

1 specimen (MB.C.18623)

1 specimen (MB.C.18624)

Trimorphoceras teguentourense $\mathrm{n}$. $\mathrm{sp}$.

Trimorphoceras absolutum Ebbighausen et al., 2010

2 specimens (MB.C.18625.1-2)

Trimorphoceras molestum Ebbighausen et al., 2010

1 specimen (MB.C.18626)

1 specimen (MB.C.18627)

Dzhaprakoceras dzhazairense Ebbighausen et al., 2010

10 specimens (MB.C.18628.1-10)

South-southwest of Jebel Mouima (Ahnet); $25.7739^{\circ} \mathrm{N}, 2.8147^{\circ}$ E (Wendt and Kaufmann Coll.):

Dzhaprakoceras dzhazairense Ebbighausen et al., $2010 \quad 1$ specimen (MB.C.18629)

Hassi Sguilma 17 km north-west of Béni Abbès; 30.2194 ${ }^{\circ} \mathrm{N}, 2.3147^{\circ} \mathrm{W}$ (Bockwinkel, Ebbighausen and Korn 2003 Coll.):

Irinoceras $\mathrm{sp}$.

1 specimen (MB.C.18630)

Ammonellipsites sguilmense $\mathrm{n}$. $\mathrm{sp}$.

Muensteroceras beniabbesense $\mathrm{n}$. $\mathrm{sp}$.

2 specimens (MB.C.18631.1-2)

Muensteroceras sp.

4 specimens (MB.C.18632.1-4)

Eurites temertassetensis n. sp.

Eurites sp.

1 specimen (MB.C.18633)

1 specimen (MB.C.18634)

3 specimens (MB.C.18635.1-3)

Trimorphoceras crassilens Ebbighausen et al., 2010

1 specimen (MB.C.18636)

Dzhaprakoceras dzhazairense Ebbighausen et al., $2010 \quad 1$ specimen (MB.C.18637)

Merocanites sp.

1 specimen (MB.C.18707)

\section{Systematic Palaeontology}

The descriptive part of this monograph will mainly focus on the illustration and morphometric analysis of the species with particular attention to their ontogenetic de- velopment, where possible. The key for the description of the species, including explanation of methods, is published in this volume by Korn (2010). Sutural terminology follows Korn et al. (2003).

Order Goniatitida Hyatt, 1884

Suborder Goniatitina Hyatt, 1884

Superfamily Pericyclaceae Hyatt, 1900

Family Pericyclidae Hyatt, 1900

Subfamily Ammonellipsitinae Riley, 1996

\section{Ammonellipsites Parkinson, 1822}

For a detailed discussion of the genus, see Ebbighausen et al. (2010).

\section{Ammonellipsites sguilmensis n. sp.}

Figures 3, 4

1961 Pericyclus plicatilis. - Pareyn, p. 138, pl. 12, figs 9-12.

1961 Pericyclus nikitini. - Pareyn, p. 140, pl. 12, figs 7, 8.

Derivation of name. After the type locality.

Holotype. Specimen MB.C.18631.1, illustrated in Figure 3.

Type locality and horizon. Hassi Sguilma (17 km north-west of Béni Abbès, Algeria); Hassi Sguilma Formation (Ammonellipsites-Merocanites Assemblage).

Material. The holotype. 
Diagnosis. Ammonellipsites with a thickly discoidal, subevolute conch at $30 \mathrm{~mm} \mathrm{dm}$; umbilical margin broadly rounded, umbilical wall convex; aperture low. Ornament with 75-80 sharp equidistant ribs per volution, course convex and slightly rursiradiate with shallow ventral sinus. Suture line with very narrow, V-shaped external lobe with subparallel and gently sinuous flanks and low median saddle; ventrolateral saddle subacute, adventive lobe narrow and lanceolate, symmetric.

Table 1. Conch shape (Fig. 4A) of Ammonellipsites sguilmensis n. sp.

\begin{tabular}{llll}
\hline $\mathrm{dm}$ & conch shape & whorl cross section shape & aperture \\
\hline $30 \mathrm{~mm}$ & thickly discoidal; subevolute & moderately depressed; moderately embracing & low \\
& $($ ww/dm $\sim 0.54 ;$ uw/dm $\sim 0.38)$ & $($ ww/wh $\sim 1.60 ;$ IZR $\sim 0.30)$ & $($ WER $\sim 1.72)$
\end{tabular}

Table 2. Conch dimensions (in mm) and proportions for reference specimens of Ammonellipsites sguilmensis n. sp.

\begin{tabular}{llllllllllll}
\hline & $\mathrm{dm}$ & ww & wh & uw & ah & ww/dm & ww/wh & uw/dm & WER & IZR \\
\hline holotype MB.C.18631.1 & 30.7 & 16.7 & 10.5 & 11.8 & 7.3 & 0.54 & 1.59 & 0.38 & 1.72 & 0.30 \\
\hline
\end{tabular}

Table 3. Suture line proportions (Fig. 4B) for Ammonellipsites sguilmensis n. sp.

\begin{tabular}{lllllll}
\hline specimen & at $\mathrm{dm}$ & EL w/d & EL/VLS & EL/AL & MS h & VLS w/h \\
\hline holotype MB.C.18631.1 & c. $23.0 \mathrm{~mm}$ & 0.42 & 1.04 & 1.05 & 0.27 & 0.41 \\
\hline
\end{tabular}

Discussion. Ammonellipsites sguilmensis can be separated from most of the other species of the genus by its broadly rounded umbilical margin, which is narrowly rounded or subangular in the other species. The moderately wide umbilicus is another criterion for separation of A. sguilmensis from many other species. A. menchikoffi Ebbighausen et al., 2010 and $A$. conradae Ebbighausen et al., 2010 from the Dalle à Merocanites have similar conchs, but differ in the V-shaped adventive lobe, which is lanceolate in A. sguilmensis. In general, the lanceolate adventive lobe is a character that separates A. sguilmensis from most of the other members of the genus Ammonellipsites.

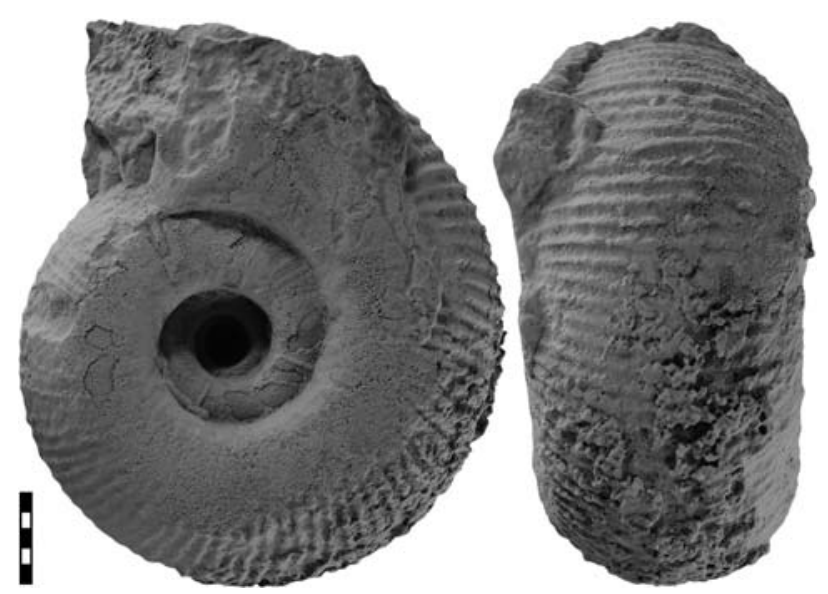

Figure 3. Ammonellipsites sguilmensis n. sp. from Hassi Sguilma, holotype MB.C.18631.1; $\times 2.0$.

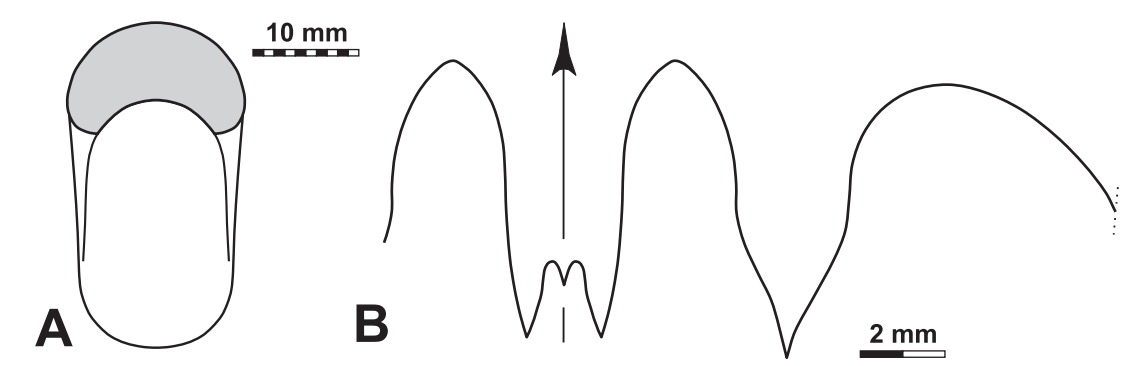

Figure 4. Ammonellipsites sguilmensis n. sp. from Hassi Sguilma. A. Dorsal view of holotype MB.C.18631.1; $\times 1.0$. B. Suture line of holotype MB.C.18631.1, at $14.0 \mathrm{~mm} w w, 9.2 \mathrm{~mm}$ wh; $\times 4.0$. 
Family Muensteroceratidae Librovitch, 1957

\section{Muensteroceras Hyatt, 1884}

For a detailed discussion of the genus, see Korn et al. (2010b).

\section{Muensteroceras beniabbesense $\mathbf{n}$. sp.}

Figures 5, 6

1961 Münsteroceras mitchelli. - Pareyn, p. 98, pl. 8, figs 8, 9.

Derivation of name. After the town of Béni Abbès.

Holotype. Specimen MB.C.18632.1, illustrated in Figure 5.

Type locality and horizon. Hassi Sguilma (17 km north-west of Béni Abbès, Algeria); Hassi Sguilma Formation (Ammonellipsites-Merocanites Assemblage).

Material. Four specimens up to $70 \mathrm{~mm}$ conch diameter.

Diagnosis. Muensteroceras with a subinvolute conch throughout ontogeny, shape thickly pachyconic at $10 \mathrm{~mm}$ and thinly to thickly discoidal at $60 \mathrm{~mm} \mathrm{dm}$; umbilical margin subangular in all growth stages, umbilical wall steep or slightly oblique; aperture moderately high at growth stages above $6 \mathrm{~mm} \mathrm{dm}$. Ornament with coarse biconvex growth lines, course biconvex with very low lateral sinus and deep ventral sinus, direction rectiradiate; numerous strong constrictions parallel to the growth lines. Suture line in the adult stage with very narrow, parallel-sided external lobe and very low median saddle; ventrolateral saddle asymmetric, broadly rounded; adventive lobe V-shaped with gently incurved ventral flank and weekly curved dorsal flank.

Table 4. Conch ontogeny (Figs 6A, C-E) of Muensteroceras beniabbesense n. sp.

\begin{tabular}{llll}
\hline $\mathrm{dm}$ & conch shape & whorl cross section shape & aperture \\
\hline $10 \mathrm{~mm}$ & thickly pachyconic; subinvolute & moderately depressed; very strongly embracing & moderate \\
& $($ ww/dm $\sim 0.74 ;$ uw/dm $\sim 0.20)$ & $($ ww/wh $\sim 1.60 ;$ IZR $\sim 0.45)$ & $($ WER $\sim 1.78)$ \\
$30 \mathrm{~mm}$ & thickly discoidal; subinvolute & weakly depressed; very strongly embracing & moderate \\
& $($ ww/dm $\sim 0.54 ;$ uw/dm $\sim 0.20)$ & $($ ww/wh $\sim 1.20 ;$ IZR $\sim 0.45)$ & $($ WER $\sim 1.80)$ \\
$60 \mathrm{~mm}$ & thickly discoidal; subinvolute & weakly depressed; very strongly embracing & moderate \\
& $($ ww/dm $\sim 0.50 ;$ uw/dm $\sim 0.20)$ & $($ ww/wh $\sim 1.20 ;$ IZR $\sim 0.45)$ & $($ WER $\sim 1.76)$
\end{tabular}

Table 5. Conch dimensions (in $\mathrm{mm}$ ) and proportions for reference specimens of Muensteroceras beniabbesense $\mathrm{n}$. $\mathrm{sp}$.

\begin{tabular}{|c|c|c|c|c|c|c|c|c|c|c|}
\hline & $\mathrm{dm}$ & ww & wh & uw & ah & $w w / d m$ & ww/wh & $\mathrm{uw} / \mathrm{dm}$ & WER & IZR \\
\hline paratype MB.C.18632.2 & 63.4 & 29.4 & 29.1 & 12.2 & 16.5 & 0.46 & 1.01 & 0.19 & 1.83 & 0.43 \\
\hline holotype MB.C.18632.1 & 55.6 & 28.9 & 24.3 & 12.1 & 13.8 & 0.52 & 1.19 & 0.22 & 1.77 & 0.43 \\
\hline paratype MB.C.18632.4 & 30.4 & 16.5 & 13.8 & 6.3 & - & 0.54 & 1.20 & 0.21 & - & - \\
\hline
\end{tabular}

Table 6. Suture line proportions (Fig. 6B) for Muensteroceras beniabbesense n. sp.

\begin{tabular}{llllllll}
\hline specimen & at dm & EL w/d & EL/VLS & EL/AL & MS h & VLS w/h & remarks \\
\hline paratype MB.C.18632.3 & c. $54.0 \mathrm{~mm}$ & 0.41 & 0.64 & 0.88 & 0.19 & 0.64 & A lobe with concave ventral flank \\
\hline
\end{tabular}

Discussion. Muensteroceras beniabbesense belongs to the members of the genus, which possess strong biconvex constrictions. It differs from the type species M. parallelum (Hall, 1860) in the higher ww/wh ratio in comparable growth stages (ww/wh $=0.90$ at $45 \mathrm{~mm} \mathrm{dm}$ in M. parallelum and $1.10 \mathrm{in} \mathrm{M.} \mathrm{beniabbesense} \mathrm{at} \mathrm{the} \mathrm{same} \mathrm{diameter)}$ and the more slender conch.

M. koninckianum Schindewolf, 1951 (= Goniatites inconstans de Koninck, 1880) from the Calcaire Waulsortien of Belgium shows some similarities, but differs in its adult opening of the umbilicus and its subangular ventrolateral shoulder from M. beniabbesense. M. frequens Kusina, 1973 from the North Urals has a similar adult conch geometry, but differs in the much wider umbilicate juvenile stage. 


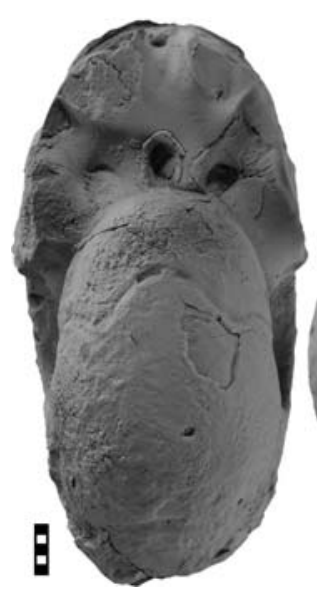

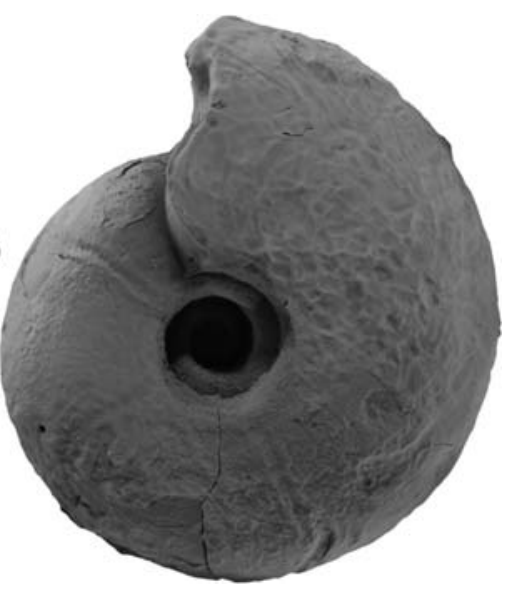

Figure 5. Muensteroceras beniabbesense n. sp. from Hassi Sguilma, holotype MB.C.18632.1; × 1.0.
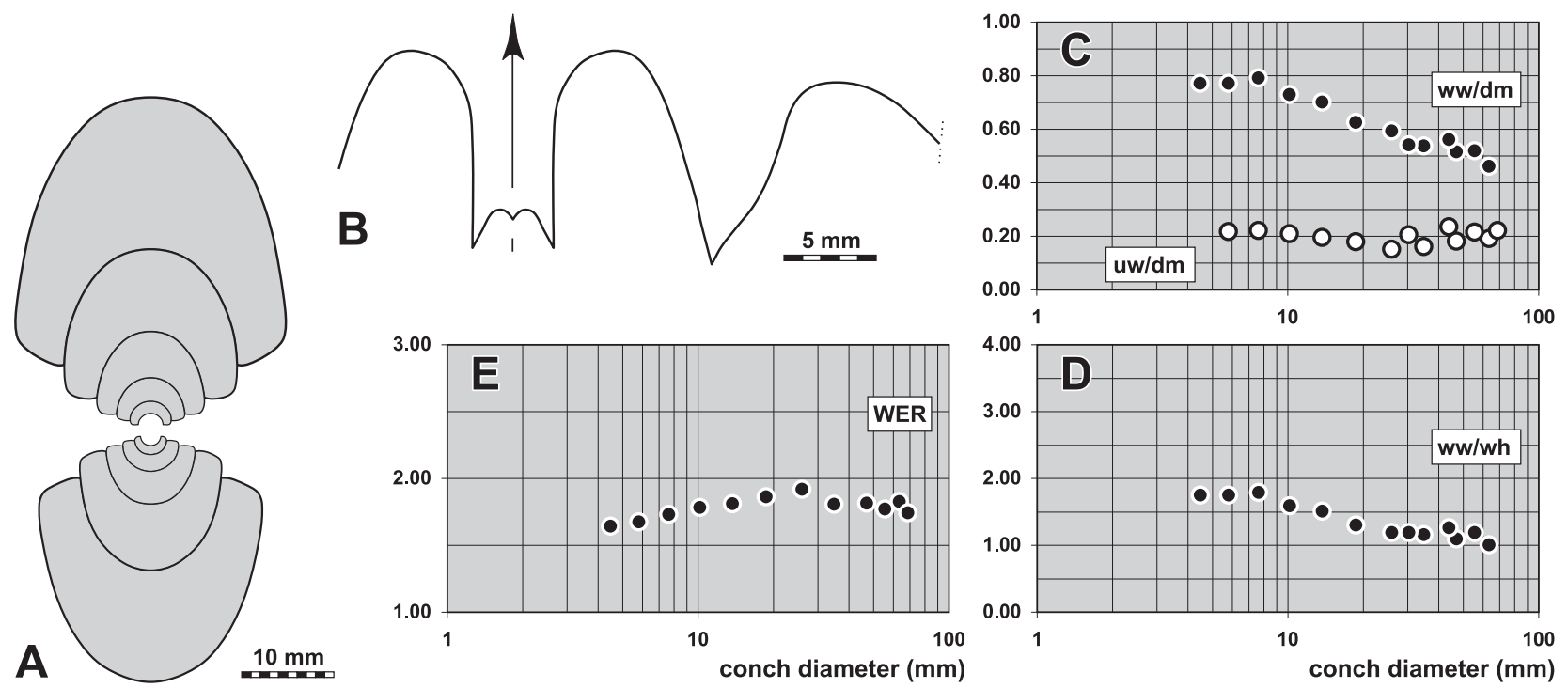

Figure 6. Muensteroceras beniabbesense n. sp. from Hassi Sguilma. A. Cross section of paratype MB.C.18632.2; $\times 1.0$. B. Suture line of paratype MB.C.18632.3, at $22.0 \mathrm{~mm}$ wh; $\times 2.0$. C-E. Ontogenetic development of the conch width index (ww/dm), umbilical width index (uw/dm), whorl width index (ww/wh), and whorl expansion rate (WER) of all available specimens.

Family Rotopericyclidae Korn, Bockwinkel \& Ebbighausen, 2010

\section{Eurites Kusina, 1973}

For a detailed discussion of the genus, see Korn et al. (2010b).

\section{Eurites temertassetensis $\mathbf{n}$. sp.}

Figures 7,8

Derivation of name. After the type locality.

Holotype. Specimen MB.C.18617.1, illustrated in Figure 7.

Type locality and horizon. Oued Temertasset, locality MOU-U (Mouydir, South Algeria); Iridet Formation (Ammonellipsites-Merocanites Assemblage).

Material. Six specimens from the type locality with conch diameters between 19 and $112 \mathrm{~mm}$ are available, of which only the holotype is well preserved and rather complete. One specimen was sectioned and shows seven whorls. One specimen from Hassi Sguilma.

Diagnosis. Eurites with a subinvolute conch throughout ontogeny with an interval of slight umbilical opening between 10 and 30 mm $\mathrm{dm}$; shape thickly pachyconic with a stouter adult stage; umbilical wall flattened, umbilical margin subangular; aperture low to moderate. Shell almost smooth; without constrictions on shell and internal mould; adult suture line with narrow V-shaped external lobe with subparallel flanks and very low median saddle; ventrolateral saddle broadly rounded; adventive lobe V-shaped, symmetric with gently curved flanks. 
Table 7. Conch ontogeny (Figs 8A-D, G-I) of Eurites temertassetensis n. sp.

\begin{tabular}{|c|c|c|c|}
\hline $\mathrm{dm}$ & conch shape & whorl cross section shape & aperture \\
\hline $4 \mathrm{~mm}$ & $\begin{array}{l}\text { thickly pachyconic; subinvolute } \\
\text { (ww/dm } \sim 0.75 ; \text { uw/dm } \sim 0.16 \text { ) }\end{array}$ & $\begin{array}{l}\text { moderately depressed; strongly embracing } \\
\text { (ww/wh } \sim 1.60 ; \text { IZR } \sim 0.44 \text { ) }\end{array}$ & $\begin{array}{l}\text { moderate } \\
(\mathrm{WER} \sim 1.85)\end{array}$ \\
\hline $10 \mathrm{~mm}$ & $\begin{array}{l}\text { thickly pachyconic; subinvolute } \\
\text { (ww/dm } \sim 0.72 ; \text { uw/dm } \sim 0.25 \text { ) }\end{array}$ & $\begin{array}{l}\text { moderately depressed; strongly embracing } \\
\text { (ww/wh } \sim 1.70 ; \text { IZR } \sim 0.40 \text { ) }\end{array}$ & $\begin{array}{l}\text { moderate } \\
(\text { WER } \sim 1.80)\end{array}$ \\
\hline $30 \mathrm{~mm}$ & $\begin{array}{l}\text { thickly pachyconic; subinvolute } \\
\text { (ww/dm } \sim 0.75 ; \text { uw/dm } \sim 0.25 \text { ) }\end{array}$ & $\begin{array}{l}\text { moderately depressed; strongly embracing } \\
\text { (ww/wh } \sim 1.75 ; \text { IZR } \sim 0.40 \text { ) }\end{array}$ & $\begin{array}{l}\text { moderate } \\
(\text { WER } \sim 1.85)\end{array}$ \\
\hline $60 \mathrm{~mm}$ & $\begin{array}{l}\text { thickly pachyconic; subinvolute } \\
\text { (ww/dm } \sim 0.82 ; \text { uw/dm } \sim 0.20 \text { ) }\end{array}$ & $\begin{array}{l}\text { moderately depressed; strongly embracing } \\
\text { (ww/wh } \sim 1.95 ; \text { IZR } \sim 0.44 \text { ) }\end{array}$ & $\begin{array}{l}\text { low } \\
\text { (WER } \sim 1.75)\end{array}$ \\
\hline
\end{tabular}

Table 8. Conch dimensions and proportions for reference specimens of Eurites temertassetensis n. sp.

\begin{tabular}{lccccccccccc}
\hline & $\mathrm{dm}$ & ww & wh & uw & ah & ww/dm & ww/wh & uw/dm & WER & IZR & \\
\hline holotype MB.C.18617.1 & 64.6 & 54.0 & 27.8 & 13.5 & 15.7 & 0.84 & 1.94 & 0.21 & 1.74 & 0.44 \\
& 51.2 & 44.8 & 22.2 & 11.2 & - & 0.88 & 2.02 & 0.22 & - & - \\
paratype MB.C.18617.2 & 24.5 & 18.9 & 9.9 & 7.4 & 5.1 & 0.77 & 1.90 & 0.30 & 1.59 & 0.49 \\
\hline
\end{tabular}

Table 9. Suture line proportions (Figs 8E, F) for Eurites temertassetensis n. sp.

\begin{tabular}{llllllll}
\hline specimen & at $\mathrm{dm}$ & EL w/d & EL/VLS & EL/AL & MS h & VLS w/h & remarks \\
\hline holotype MB.C.18617.1 & c. $46.0 \mathrm{~mm}$ & 0.44 & 0.64 & 0.84 & 0.19 & 0.70 & E lobe slightly pouched, V-shaped \\
paratype MB.C.18617.2 & c. $26.0 \mathrm{~mm}$ & 0.48 & 0.49 & 0.73 & 0.17 & 0.76 & A lobe asymmetric \\
\hline
\end{tabular}

Discussion. Eurites temertassetensis closely resembles E. commutatus Ebbighausen et al., 2010 and E. pondus Ebbighausen et al., 2010 from the Dalle à Merocanites of Timimoun, but differs from both in the diverging flanks of the external lobe, which has parallel flanks in the other two species. A further difference is the continuous opening of the umbilicus in E. temertassetensis; the umbilicus is being closed in E. commutatus by strong whorl overlap in the preadult stage. E. pondus, E. latus Kusina, 1973, and E. corpulentissimus (Schindewolf, 1951) have a wider umbilicus than E. temertassetensis. The latter two species differ also in their asymmetric adventive lobe from the new species.

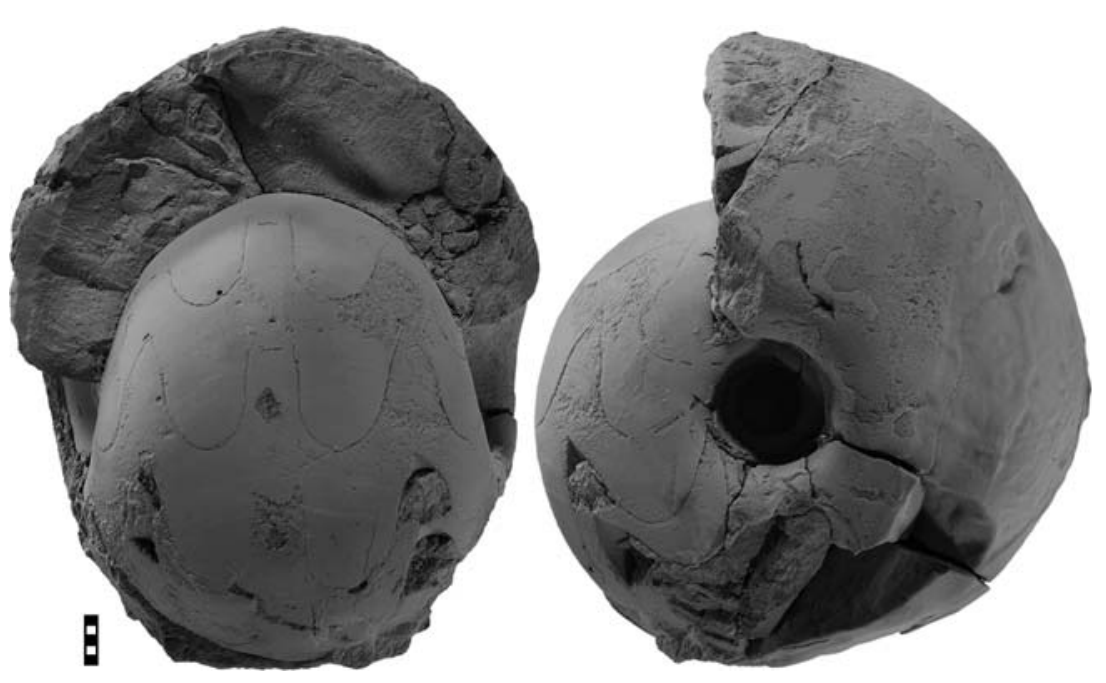

Figure 7. Eurites temertassetensis n. sp. from locality MOU-U, holotype MB.C. $18617.1 ; \times 1.0$. 

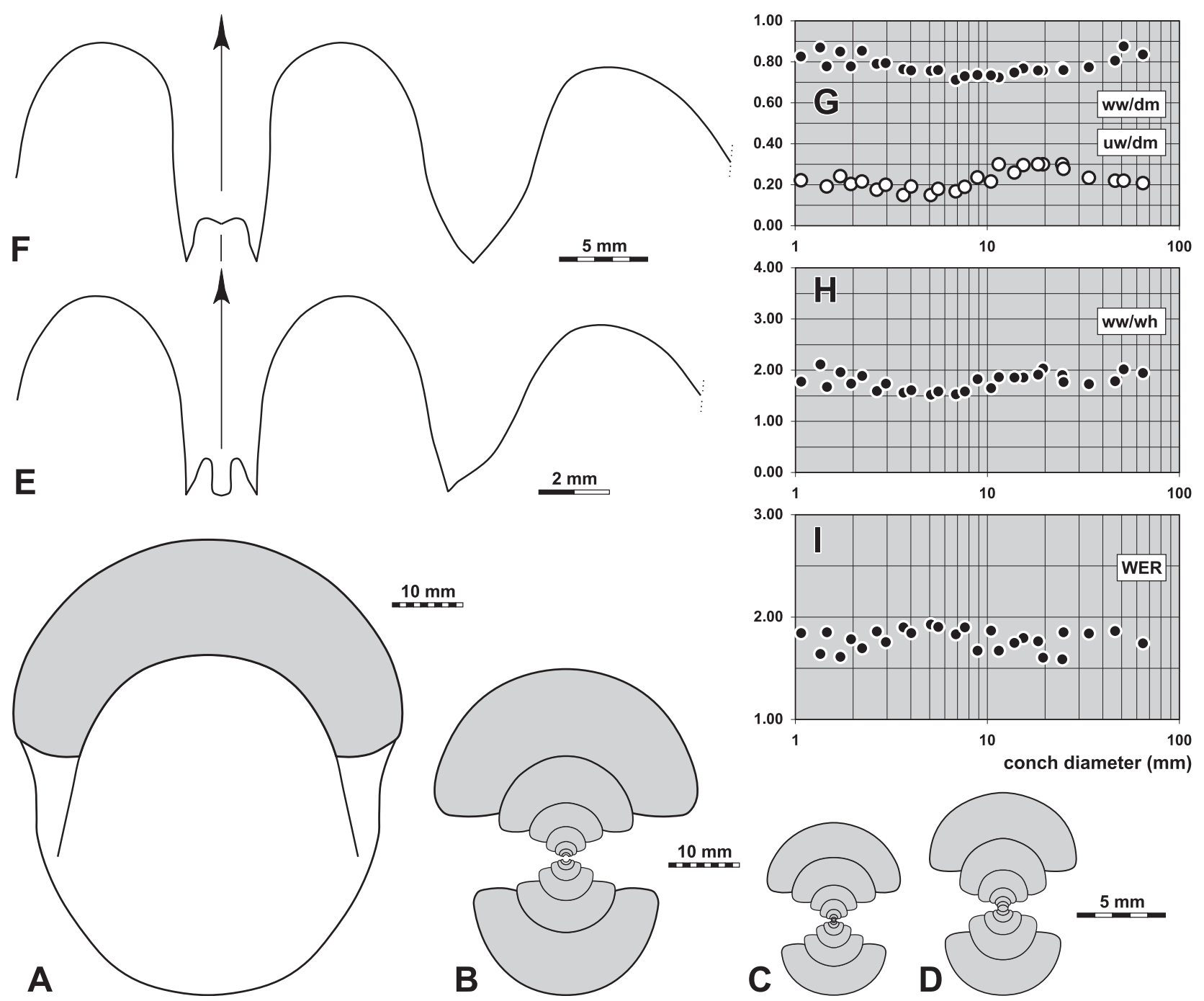

Figure 8. Eurites temertassetensis n. sp. A. Dorsal view of holotype MB.C.18617.1 from locality MOU-U; $\times 1.0$. B. Cross section of paratype MB.C.18634 from Hassi Sguilma; $\times 1.0$. C. Cross section of paratype MB.C.18617.2 from locality MOU-U; $\times 1.0$. D. Cross section (inner whorls) of the same specimen; $\times 2.5$. E. Suture line of paratype MB.C.18617.2 from locality MOU-U, at $18.4 \mathrm{~mm}$ ww, $8.8 \mathrm{~mm}$ wh; $\times 5.0$. F. Suture line of holotype MB.C.18617.1 from locality MOU-U, at $38.6 \mathrm{~mm}$ ww, $22.2 \mathrm{~mm}$ wh; $\times 2.5$. G-I. Ontogenetic development of the conch width index (ww/dm), umbilical width index (uw/dm), whorl width index (ww/ wh), and whorl expansion rate (WER) of all available specimens.

Subfamily Trimorphoceratinae Ebbighausen, Korn \& Bockwinkel, 2010

\section{Trimorphoceras Ebbighausen, Korn \& Bockwinkel, 2010}

For a detailed discussion of the genus, see Ebbighausen et al. (2010).

\section{Trimorphoceras azzelmattiense $\mathbf{n}$. sp.}

Figures 9, 10

Derivation of name. After the type locality.

Holotype. Specimen MB.C.18621, illustrated in Figure 9.

Type locality and horizon. West of Azzel Matti, locality A292 (Ahnet, South Algeria); Iridet Formation (Ammonellipsites-Merocanites Assemblage).

Material. Only the holotype with a $58 \mathrm{~mm}$ conch diameter; it is a moderately well-preserved specimen in dark reddish oolithic limestone. The specimen is slightly corroded at places, but shows shell remains as well as the suture line.

Diagnosis. Trimorphoceras with a thickly discoidal, subinvolute conch at $60 \mathrm{~mm} \mathrm{dm}$; very slow closure of the umbilicus in the adult stage; umbilical margin rounded, umbilical wall slightly flattened; aperture moderately high. Ornament with extremely fine growth-lines. Suture line with very narrow, parallel-sided external lobe and low median saddle; ventrolateral saddle broadly rounded and almost symmetric; adventive lobe strongly asymmetric. 
Table 10. Conch ontogeny (Fig. 10A) of Trimorphoceras azzelmattiense n. sp.

\begin{tabular}{llll}
\hline $\mathrm{dm}$ & conch shape & whorl cross section shape & aperture \\
\hline $58 \mathrm{~mm}$ & thickly discoidal; subinvolute & weakly depressed; very strongly embracing & moderate \\
& $($ ww/dm $\sim 0.57 ;$ uw/dm $\sim 0.24)$ & $($ ww/wh $\sim 1.15 ;$ IZR $\sim 0.46)$ & $($ WER $\sim 1.85)$
\end{tabular}

Table 11. Conch dimensions and proportions for reference specimens of Trimorphoceras azzelmattiense $\mathrm{n}$. sp.

\begin{tabular}{llllllllllll}
\hline & $\mathrm{dm}$ & ww & wh & uw & ah & ww/dm & ww/wh & uw/dm & WER & IZR & \\
\hline holotype MB.C.18621 & 58.5 & 33.6 & 29.0 & 14.0 & 15.6 & 0.57 & 1.16 & 0.24 & 1.86 & 0.46 \\
& 43.3 & 30.4 & 19.1 & 11.7 & - & 0.70 & 1.59 & 0.27 & - & - \\
\hline
\end{tabular}

Table 12. Suture line proportions (Fig. 10B) for Trimorphoceras azzelmattiense n. sp.

\begin{tabular}{llllllll}
\hline specimen & at dm & EL w/d & EL/NLS & EL/AL & MS h & VLS w/h & remarks \\
\hline holotype MB.C.18621 & $52.0 \mathrm{~mm}$ & 0.30 & 0.40 & 0.80 & 0.28 & 0.76 & A lobe strongly asymmetric \\
\hline
\end{tabular}

Discussion. The conch morphology of Trimorphoceras azzelmattiense resembles that of T. absolutum Ebbighausen et al., 2010 and T. molestum Ebbighausen et al., 2010 from the Dalle à Merocanites, but differs in the wider umbilicus $(\mathrm{ww} / \mathrm{dm}=0.24$ at $58 \mathrm{~mm} \mathrm{dm}$ in contrast to $0.10-0.15$ in T. absolutum and $0.15-0.25$ in T. molestum). This difference is mainly caused by the delayed process of closure of the umbilicus in the adult stage in T. azzelmattiense. A further difference is the much lower aperture in T. azzelmattiense at a diameter of almost $60 \mathrm{~mm}$ $(\mathrm{WER}=1.86)$ in contrast to T. absolutum and T. molestum $(1.95-2.15)$.
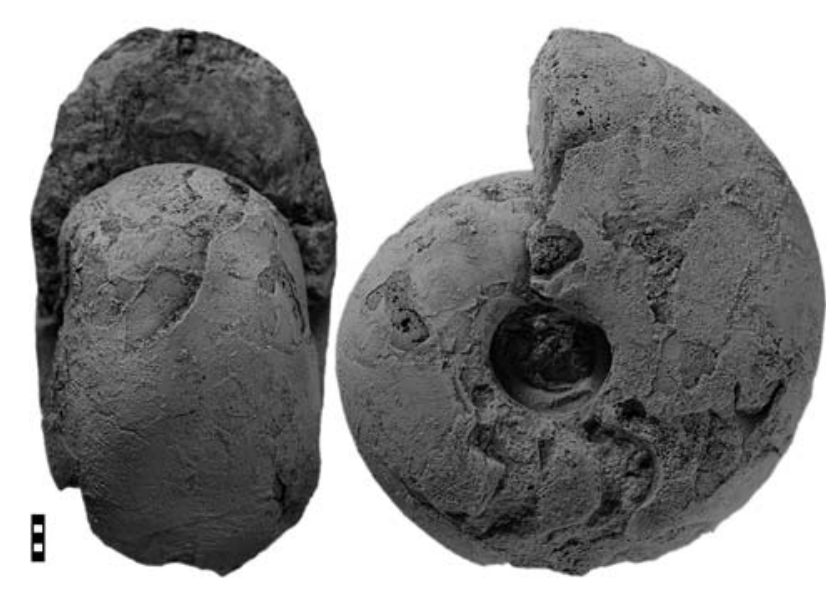

Figure 9. Trimorphoceras azzelmattiense n. sp. from Azzel Matti, holotype MB.C.18621; × 1.0.

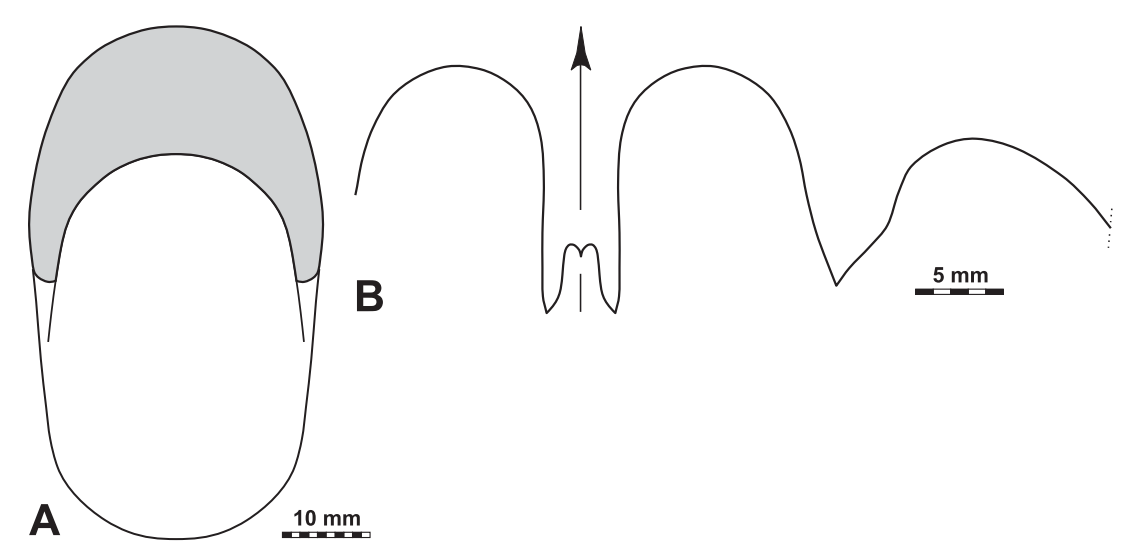

Figure 10. Trimorphoceras azzelmattiense n. sp. from Azzel Matti. A. Dorsal view of holotype MB.C.18621; $\times 1.0$. B. Suture line of holotype MB.C.18621, at $52.0 \mathrm{~mm} \mathrm{dm}, 32.5 \mathrm{~mm}$ ww, $24.0 \mathrm{~mm}$ wh; $\times 2.0$. 


\section{Trimorphoceras teguentourense $\mathbf{n}$. sp.}

Figures 11, 12

Derivation of name. After the type locality.

Holotype. Specimen MB.C.18625.1, illustrated in Figure 11.

Type locality and horizon. Erg Teguentour, locality A259/4 (Ahnet, South Algeria); Iridet Formation (Ammonellipsites-Merocanites Assemblage).

Material. Only the holotype with a $41 \mathrm{~mm}$ conch diameter and the paratype with $30 \mathrm{~mm} \mathrm{dm}$. The two specimens show the transformation from the pachyconic into the discoidal conch shape.

Diagnosis. Trimorphoceras with a thickly discoidal, subinvolute conch at $40 \mathrm{~mm} \mathrm{dm}$; umbilical margin rounded, umbilical wall convex; aperture high. Without constrictions. Suture line with very narrow, parallel-sided external lobe and very low median saddle; ventrolateral saddle broadly rounded and asymmetric; adventive lobe strongly asymmetric with slightly curved ventral flank and strongly curved dorsal flank.

Table 13. Conch ontogeny (Fig. 12A) of Trimorphoceras teguentourense $\mathrm{n} . \mathrm{sp}$.

\begin{tabular}{lllll}
\hline $\mathrm{dm}$ & conch shape & whorl cross section shape & aperture \\
\hline $30 \mathrm{~mm}$ & thinly pachyconic; subinvolute & weakly depressed; very strongly embracing & moderate \\
& $($ ww/dm $\sim 0.67 ;$ uw/dm $\sim 0.23)$ & $($ ww/wh $\sim 1.45 ;$ IZR $\sim 0.46)$ & (WER $\sim 1.77)$ & high \\
$40 \mathrm{~mm}$ & thickly discoidal; subinvolute & weakly depressed; strongly embracing & (Ww/wh $\sim 1.10 ;$ IZR $\sim 0.40)$ &
\end{tabular}

Table 14. Conch dimensions and proportions for reference specimens of Trimorphoceras teguentourense n. sp.

\begin{tabular}{lcccccccccccccc}
\hline & $\mathrm{dm}$ & ww & wh & uw & ah & ww/dm & ww/wh & uw/dm & WER & IZR & & & & \\
\hline holotype MB.C.18625.1 & 41.2 & 22.2 & 20.1 & 7.3 & 12.1 & 0.54 & 1.11 & 0.18 & 2.01 & 0.40 \\
paratype MB.C.18625.2 & 29.9 & 19.9 & 13.7 & 6.8 & 7.4 & 0.67 & 1.46 & 0.23 & 1.77 & 0.46 & \\
\hline
\end{tabular}

Table 15. Suture line proportions (Fig. 12B) for Trimorphoceras teguentourense n. sp.

\begin{tabular}{llllllll}
\hline specimen & at dm & EL w/d & EL/VLS & EL/AL & MS h & VLS w/h & remarks \\
\hline holotype MB.C.18625.1 & $36.7 \mathrm{~mm}$ & 0.44 & 0.67 & 1.02 & 0.19 & 0.66 & A lobe strongly asymmetric \\
\hline
\end{tabular}
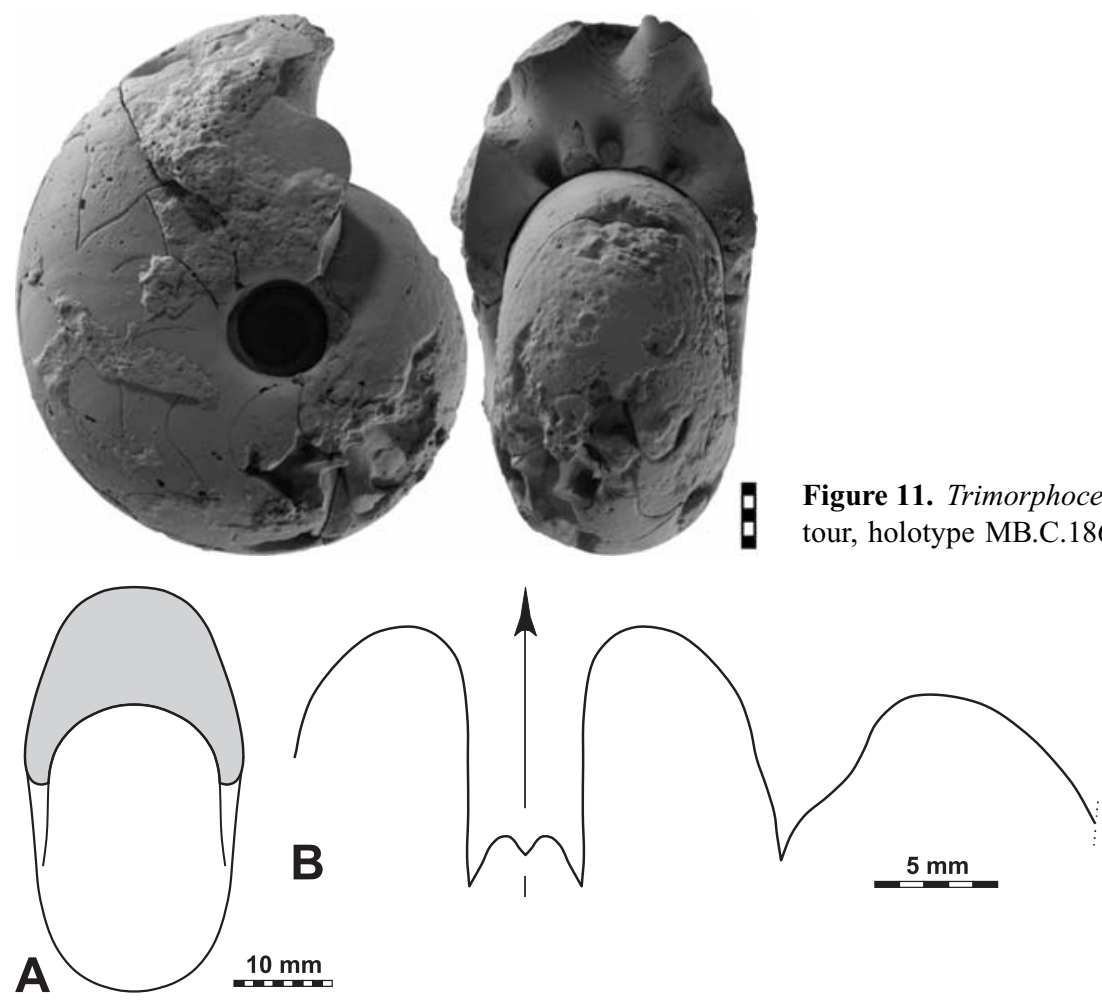

Figure 12. Trimorphoceras teguentourense n. sp. from Erg Teguentour. A. Dorsal view of holotype MB.C. $18625.1 ; \times 1.0$. B. Suture line of holotype MB.C.18625.1, at $36.7 \mathrm{~mm}$ dm, $21.7 \mathrm{~mm}$ ww, $18.2 \mathrm{~mm}$ wh; $\times 2.5$. 
Discussion. Trimorphoceras teguentourense belongs to the more discoidal species of the genus and is comparable to T. crassilens Ebbighausen et al., 2010. The main difference to the species from the Dalle à Merocanites is the wider umbilicus of T. teguentourense in comparable growth stages (at $30 \mathrm{~mm} \mathrm{dm:} \mathrm{uw/dm} \sim 0.23$ in T. teguentourense and $0.10-0.20$ in T. crassilens; at $40 \mathrm{~mm} \mathrm{dm:} \mathrm{uw/dm} \sim 0.18$ in T. teguentourense and $0.07-0.15$ in T. crassilens).

Family Maxigoniatitidae Korn, Klug \& Mapes, 1999

Subfamily Dzhaprakoceratinae Korn, Bockwinkel \& Ebbighausen, 2010

For a detailed discussion of the subfamily, see Korn et al. (2010b).

\section{Dzhaprakoceras Popov, 1965}

For a detailed discussion of the genus, see Korn et al. (2010b).

\section{Dzhaprakoceras dzhazairense Ebbighausen, Korn \& Bockwinkel, 2010}

Figure 13

Holotype. Specimen MB.C.18615.1, illustrated by Ebbighausen et al. (2010) in Figure 41A.

Type locality and horizon. Sebkha de Timimoun, locality TIM-C7 (12 km SW of Timimoun, Algeria); Ammonellipsites-Merocanites Assemblage.

Material. This species is probably the most common in the Iridet Formation; ten specimens between 35 and approximately 95 mm conch diameter are available from the Erg Teguentour. The largest of the specimens, of which most are poorly preserved, (MB.C.18628.1) has a completely preserved phragmocone, suggesting that the diameter plus body chamber measured about $160 \mathrm{~mm}$ in diameter.

Diagnosis. See Ebbighausen et al (2010).

Table 16. Conch dimensions and proportions for reference specimens of Dzhaprakoceras dzhazairense Ebbighausen et al. (2010).

\begin{tabular}{|c|c|c|c|c|c|c|c|c|c|c|}
\hline & $d m$ & ww & wh & uw & ah & $w w / d m$ & ww/wh & uw/dm & WER & IZR \\
\hline MB.C. 18628.2 & 53.7 & 23.4 & 28.4 & 3.8 & 16.7 & 0.44 & 0.82 & 0.07 & 2.01 & 0.41 \\
\hline MB.C. 18628.3 & 41.5 & 19.6 & 24.6 & 3.3 & 13.3 & 0.47 & 0.79 & 0.08 & 2.16 & 0.46 \\
\hline MB.C.18628.4 & 35.9 & 18.4 & 20.8 & 2.1 & - & 0.51 & 0.88 & 0.06 & - & - \\
\hline
\end{tabular}

Table 17. Suture line proportions (Fig. 13) for Dzhaprakoceras dzhazairense Ebbighausen et al. (2010).

\begin{tabular}{llllllll}
\hline specimen & at dm & EL w/d & EL/VLS & EL/AL & MS h & VLS w/h & remarks \\
\hline MB.C.18628.1 & c. $90.0 \mathrm{~mm}$ & 0.33 & 0.52 & 0.80 & 0.33 & 0.63 & E lobe affected by previous SL \\
\hline
\end{tabular}

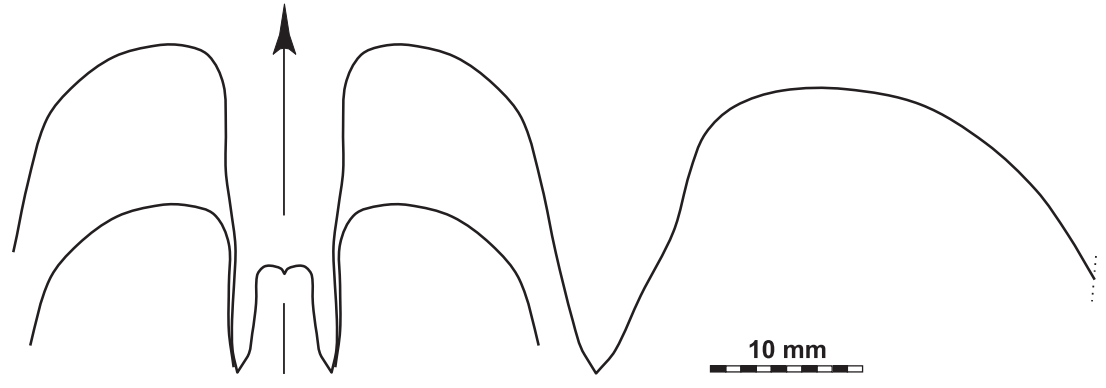

(C) 2010 WILEY-VCH Verlag GmbH \& Co. KGaA, Weinheim
Figure 13. Dzhaprakoceras dzhazairense Ebbighausen et al. 2010 from Erg Teguentour. Suture line of specimen MB.C.18628.1, at $34.0 \mathrm{~mm}$ ww, $51.0 \mathrm{~mm}$ wh; $\times 1.5$. 


\section{Acknowledgements}

We are indebted to the Algerian authorities for their permission for us to undertake field work. D.K. acknowledges the Deutsche Forschungsgemeinschaft (DFG) for financial support (project KO1829/ 3-1). Jobst Wendt and Bernd Kaufmann (Tübingen) are acknowledged for the collection of most of the material from the Ahnet and Mouydir. Dieter Weyer (Berlin) joint us during the first field session and contributed significantly to the collection. Technical support was provided by Wolfgang Gerber (Tübingen) for the photography the specimens and by Evelin Stenzel (Berlin) for preparation of the material. We also thank Sonny Walton (Potsdam) for proofreading the manuscript and R. Thomas Becker (Münster) as well as Christian Klug (Zürich) for reviewing the article.

\section{References}

Bockwinkel, J., Korn, D. \& Ebbighausen, V. 2010. The ammonoids from the Argiles de Timimoun of Timimoun (Early and Middle Viséan; Gourara, Algeria). - Fossil Record 13 (1): 215-278.

Conrad, J. 1984. Les séries Carbonifères du Sahara Central Algérien stratigraphie, sédimentation, évolution structurale. - Université de Droit, d'Economie et des Sciences d'Aix Marseille, Thèse de Doctorat d'Etat dès-Sciences naturelles, Marseille.

Ebbighausen, V., Korn, D. \& Bockwinkel, J. 2010. The ammonoids from the Dalle à Merocanites of Timimoun (Late TournaisianEarly Viséan; Gourara, Algeria). - Fossil Record 13 (1): 153202.

Hyatt, A. 1883-1884. Genera of fossil cephalopods. - Proceedings of the Boston Society of Natural History 22: 253-338 (253-272 publ.1883, 273-338 publ.1884).

Hyatt, A. 1900. Tetrabranchiate Cephalopoda. In Zittel, K. v. (ed.; transl. \& ed. by C. R. Eastman). Text-book of palaeontology, volume 1, 1st edition. McMillan, New York: pp. 502-604.

Koninck, L. G. de 1880. Faune du Calcaire Carbonifère de la Belgique, deuxième partie, Genres Gyroceras, Cyrtoceras, Gomphoceras, Orthoceras, Subclymenia et Goniatites. - Annales du Musée Royal d'Histoire Naturelle de Belgique 5: 1-333.

Korn, D. 2010. A key for the description of Palaeozoic ammonoids. Fossil Record 13 (1): 5-12.
Korn, D., Belka, Z., Fröhlich, S., Rücklin, M. \& Wendt, J. 2004. The youngest African clymeniids (Ammonoidea, Late Devonian) failed survivors of the Hangenberg Event. - Lethaia 37: 307315.

Korn, D., Bockwinkel, J. \& Ebbighausen, V. 2007. The Tournaisian and Viséan ammonoid stratigraphy in North Africa. - Neues Jahrbuch für Geologie und Paläontologie 243 (2): 127-148.

Korn, D., Ebbighausen, V. \& Bockwinkel, J. 2010a. The ammonoids from the Grès du Kahla supérieur of Timimoun (Middle-early Late Tournaisian; Gourara, Algeria). - Fossil Record 13 (1): 13-34

Korn, D., Bockwinkel, J. \& Ebbighausen, V. 2010b. The ammonoids from the Argiles de Teguentour of Oued Temertasset (early Late Tournaisian; Mouydir, Algeria). - Fossil Record 13 (1): 35-152.

Korn, D., Ebbighausen, V., Bockwinkel, J. \& Klug, C. 2003. The Amode sutural ontogeny in prolecanitid ammonoids. - Palaeontology 46 (6): 1123-1132.

Korn, D., Klug, C. \& Mapes, R. H. 1999. Viséan and Early Namurian Ammonoids from the Tafilalt (Eastern Anti-Atlas, Morocco). Abhandlungen der Geologischen Bundesanstalt 54: 345-375.

Kusina, L. F. 1973. K revizii roda Muensteroceras. - Paleontologicheskiy Zhurnal 1973 (3): 14-25.

Librovitch, L. S. 1957. O nekotorykh novykh gruppakh goniatitov iz kamennougol'nykh otlozheniy SSSR. - Ezhegodnik Vsesoyuznogo Paleontologicheskogo Obshchestva 16: 246-272.

Menchikoff, N. 1930. Recherches géologiques et morphologiques dans le nord du Sahara occidental. - Revue de Géographie physique et de Géologie dynamique 3 (2): 103-247.

Pareyn, C. 1961. Les Massifs Carbonifères du Sahara Sud-Oranais. Tome II. Paléontologie stratigraphique. - Publications du Centre de Recherches Sahariennes, Série Géologie 1: 1-244.

Parkinson, J. 1822. Introduction to the study of fossil organic remains. I. Sherwood, Neely and. Jones, London: VII + 346 pp..

Popov, A. V. 1965. Novye vizeyskie ammonoidei Tyan-Shanya. - Paleontologicheskiy Zhurnal 1965 (2): 35-49.

Riley, N. J. 1996. Mid-Dinantian ammonoids from the Craven Basin, northwest England. - Special papers in Palaeontology 53: 1-87.

Schindewolf, O. H. 1951. Über ein neues Vorkommen unterkarbonischer Pericyclus-Schichten im Oberharz. - Neues Jahrbuch für Geologie und Paläontologie, Abhandlungen 93 (1): 23-116.

Wendt, J., Kaufmann, B., Belka, Z. \& Korn, D. 2009. Carboniferous stratigraphy and depositional environments in the Ahnet Mouydir area (Algerian Sahara). - Facies 55 (3): 443-472. 